\title{
The Autobiographical Novels of Sidonie-Gabrielle Colette and Virginia Woolf: A Comparative Study
}

\author{
Zahra Jannessari Ladani*, Safoura Tork Ladani \\ English Department, University of Isfahan, Isfahan, Islamic Republic of Iran \\ *E-mail address: z.jannessari@fgn.ui.ac.ir
}

\begin{abstract}
Keywords: Sidonie-Gabrielle Colette; Virginia Woolf; Novel; Autobiographical; Fiction; Self; Author.

ABSTRACT. Autobiographical mode of writing informs the works of many novelists, consciously or unconsciously. There are, however, diverse techniques for formulating these conscious or unconscious autobiographical interpolations in literary works. This essay aims to study the works of Sidonie-Gabreille Colette and Virginia Woolf to trace the nuances of the autobiographical mode in two contemporary female writers from different nations. We do not aim at proving that these two writers deploy the autobiographical mode in their writings, but how similar and different their autobiographical techniques in the creation of fiction are. Therefore, Colette's and Woolf's novels, in general, will be compared and contrasted with an eye on their self-defined strategies for the development of autobiographical fiction.
\end{abstract}

\section{INTRODUCTION}

The works of Sidonie-Gabrielle Colette (1873-1945) and Virginia Woolf (1882-1941) have their roots in the life context of the two writers. Colette, a French novelist, invites her audience to an amiable conversation in her works despite her concealing art, and despite the difficulty of recognizing her dual spirit through her fiction. Colette endeavors to flee ambivalence and duality by portraying her diverse selves through her central characters, thus succumbing to fantasy and trespassing the traditional narrative structures. Colette's autobiographical mind reveals her belief in the fantastic nature of reality (facts). Colette also lays down a new feminine style which frankly distinguishes itself from the traditional narrative by her deliberate integration of the fictional and the autobiographical.

Colette's English contemporary, Virginia Woolf, shows a similar interest in the autobiographical mode in several of her novels, most famously Mrs. Dalloway (1925) and To the Lighthouse (1927). She is the writer of some biographies, including Flush (1933) and Roger Fry (1940) as well as essays, criticism, and commentaries postulating her opinions about the theory of fiction and (auto)biographical writing, such as "Modern Fiction" (1921), "The New Biography" (1927), "The Art of Biography" (1939). Given that Colette and Woolf were contemporaneous witnesses of the last decades of the nineteenth and the first four decades of the twentieth century, and given that both were attracted to autobiographical fiction, they deserve to be studied comparatively. Besides, such a study is unprecedented.

\section{DISCUSSION}

\subsection{Sidonie-Gabrielle Colette}

For many writers, writing is a response to a vague and unbridled conversion of feelings, beliefs, and experience in life. Colette, however, denied the existence of any such desire throughout her career, and it was only a chance when she started writing after meeting and marrying her first mate, Henry Gauthier Villars, who brought her great talent to her attention for the first time. Colette's body of works comprised fiction, a means for representing her autobiographical selves freely and without being obliged to keep faithful to factual details. She set out with La Maison de Caludine (1922), and continued her exploration of this autobiographical self in La Naissance de Jour (1928) and Sido (1929). 
Lejeune recognizes the author's identity as the juncture where autobiographical fiction diverges from current autobiography: "It is the name of the author that provides the ground for discussing autobiography." He brings together the names of "Colette" that represents a real person-the writer of a short story collection - and "Claudine" who is the fictional female protagonist - the narrator of the stories collected under her name (Le Pacte 24) — and identifies them as one being. Baladier, too, pinpoints a similar distinction between autobiography and fiction: the former seems to represent the reality whereas the latter is shaped around creativity and objectification. Thus, he identifies Colette's fiction and autobiography as an attempt to release and restore the irreplaceable expressions of a woman who proclaims her "self" through narrating her status (86).

One of the influential techniques employed to represent the "self" in Colette's works, particularly in Claudine, is mirroring, which frequently appears as the image of a mirror where the female protagonist can watch her visage. The mirror image helps Colette to establish a dialogue between two Cluadines, thus seeking the creation of her "self". This technique provides Colette with an alternate space where she would flee from her routine life. The mirror image is a vivid metaphor for self-consciousness where the hidden "self" comes to the fore in a dialogue with the "other".

Among the diverse selves reflected in the mirror is the "Claudine" of the beginning stories who, as a famous person since 1900, is less honest, and whose naivety, mischief, and utter freedom highlight a fresh tone and spicy speech which is precisely Colette's own voice. In the play between the author and the characters, the mirror reflects the fierce and uncompromising fight between Colette's unbending arrogance - since she has turned into an impenetrable character-and a more humanitarian portrait of Colette who is capable of absorbing autobiographical innovations. However, this mirroring technique gives its place to the technique of the mask (which is withdrawn through the story). In Les Vrilles de la Vigne (1908), the theme of Janus-faced personalities is no longer pursued, but the real identity of Colette is emphasized. Here, she speaks about her impatience for freedom from limitations and her desire to seek knowledge of truth: "Claudine laughs and calls out: 'Hello my confidante!' But I shake my head and respond: 'I'm not your confidante. Do you have anything but this misapprehension which puts us together? You're Claudine and I'm Colette... Oh my arrogant Other! I shall never again adorn myself by what belongs to you!" (Les Vrilles 98-99). It is not clear what the reference of the pronoun "I" is, whether it is the author of a new story who loves animals, or it arises from a context which reminisces her childhood. Indeed, the author reveals her interest in masks and prefers to rely on a half-voice. Her dreams and regrets find a niche among the ellipses and white blanks on the page. Colette trespasses the conventions of autobiography by revealing all her faces and contradictory dimensions at the apex of transformation: now a dancer, now a lover, now a young woman. Colette adopts the firstperson narrator to establish a dialogue with the present as well as reconstruct her childhood world (Itti 107-8).

Colette's third technique is "makeup," improving the face by cosmetics. Colette's La Vagabonde (1910) portrays the scarred face of a woman who has to sustain after divorce by playing music in the Music-Hall. In this novel, the narrator depicts her rejected spouse and her mentality vividly. Here the writer creates and identifies herself with a new character named Renee Nere. Interweaving fiction and autobiography, Colette blurs the boundary between the different novelistic subgenres, in this case, internal monologue in journalistic and epistolary modes (Baude 112). Colette maintains: "the reincarnation of truth is not realized but in dance, light, freedom, and music. Truth is nothing but the harmony of thought reflected in beautiful forms and movements" ( $L a$ Vagabonde 54). Thus, the themes of makeup and scene layout allow the writer to analyze the female as a representative kind. In La Vagabonde, the female protagonist introduces herself as an agent observing her own action (Collado 144). Rene represents other images of hers besides her image in the mirror, on the scene, and on page. The narrator readily modifies her appearance, and shows a great interest in makeup. The text is also a kind of makeup: Colette adopts the strategy of concealing and absorption. The "I" of the narrator is born through felt pain in the past and the alterations in the writer herself. The "I" created besides the personality of the writer is an integrated 
"I", a mirror which renders a significant tool for self-knowledge beyond the persona. Colette preserves her autobiographical presence as a narrator in this novel through Renee Nere.

One more strategy to represent the autobiographical dimensions of Colette's fiction writing is her appeal to heredity as a device. This technique informs La Maison de Claudine as "very decisive for it is with the publication of this novel that the personality of the mother is distinguished from Colette's herself... and endows the writer's mind with significance and order... Thus, Colette no longer pursues her 'self,' but discovers that in the past" (Ferrier-Caverivière 21). La Maison de Claudine portrays the novelist's childhood and family and the world where she grew up. Here, autobiography is not interwoven with either the personal image of the writer or the story of her memories. The structure of the work renders an appealing and exciting narration (Lejeune, L'Autobiographie 197). Since the novel does not narrate the writer's life in a time sequence, it looks like a collection of fragmentary childhood memories.

La Sido also conveys Colette's picture of her childhood, a golden phase in her life. She narrates her adolescent years and by reminiscing slices of those days, she highlights the crucial times in the history of her character. In this way, she indicates to the reader where she got her roots: the lessons she learned from her mother, Sido. Therefore, the novel turns into a long hymn for the image of the mother. In this way, the image of Sido gives way to the image of the family, and the exploration of the "self" is channeled into a linear-hereditary route whereby filial relations emerge. Thus Colette's "self" is reconstructed through identification with her parents.

Colette has been criticized for her intervention of reality to give a portrait of herself (Castillo). The fact is that Colette gives her audience clues as to the biographical nature of her novels, but simultaneously provides them with modifications. In La Naissance $d u$ jour, Colette asks: "Why should I jut down my fiction on paper? Does this paper accept what I know as mine, what I try to conceal, and what I create?" (103). So as Marks notes, one could find two distinct periods in Colette's literary career: one with novels narrated from the first person point of view, the other with writings in which Colette distances herself from the female protagonists; these two periods are merged in Colette's collections of her memories (99).

In her literary transformation, Colette notably progresses through a two-dimensional course as both a writer and a woman. The thing is that she is dexterous in the art of "secrecy" (Hériat 9-15; Laisné 24-26). For Colette, woman is predestined to be adorned with lies and duplicity, and literary creation is the only effective way of narrating and revealing the self from behind the disguises. Thus, in fiction, everything is probable and acceptable, even caricatural hyperboles. Despite the diversity of Colette's novels, one could claim that she has written only one book in her life, and this is the book where she indefatigably devotes herself to one major motif, i.e. the transformation of personal emotions. Without theorizing about her fiction, Colette materializes the volition of the ubiquitous narrator, and in this way, remodels the genres of the novel and the autobiography through non-conventional techniques. Colette draws on normal life experiences as her subject matter, and combines fact and fiction to deliver a contradictory image of herself. Unlike traditional novelists who drew on formal realism as a device to depict the surface of life, Colette directs the attention to the inner world and foregrounds her mind in fiction. In this process, she works out mental data and transforms her life memories. Thus, Colette recognizes the art of autobiographical novel as a necessary achievement of modern aesthetics.

\subsection{Virginia Woolf}

Woolf belonged to the Bloomsbury circle which gathered together important modernist artists, musicians, writers, philosophers, etc. as a group that discussed the modern world, the new directions life should take in its context, and the way literature, arts and philosophy should react to it. The members of this group included Virginia and Leonard Woolf, John Maynard Keynes, E. M. Forster, Lytton Strachey and Clive Bell. A glimpse at these names shows that they all rose from the Victorian culture of nineteenth-century England, and that all were sever critics of that culture. Now part of this culture was the prominent Victorians' zest for biographical mode of writing. Woolf's own father, Leslie Stephen, was a renowned Victorian author, editor and critic. He was famous for 
being the first editor of Dictionary of National Biography. So Woolf ineluctably was under his influence in the writing and reading of biographies, so much so that such tasks remained her major concerns throughout her literary life. This resulted in "The New Biography" and "The Art of Biography" whereby Woolf formulated her critical theories on biography and biographers.

In "The New Biography," Woolf criticizes Sir Sidney Lee's life of Shakespeare and Edward VII as being "dull," "unbearable," and conveying truth incapable of transmitting "personality" (14950). She adds: "For in order that the light of personality may shine through, facts must be manipulated; some must be brightened; others shaded; yet, in the process, they must never lose their integrity" (150). Woolf's statement indicates that tinges of fictionality should inevitably infiltrate a biographical account to make it "give off for ever and ever grains of energy, atoms of light" (149). This process is fulfilled in Woolf's own works, including her novels.

Woolf's novels are fraught with (auto)biographical signs, since fiction writers cannot escape subjectivity at the same time that they have no other resource for their fictional material than their personal and experiential reservoir. Woolf's To the Lighthouse and Mrs. Dalloway are very telling examples of this. The former reveals Woolf's childhood, her family, and environmental whereabouts which influenced her character. This novel simultaneously displays Woolf's techniques for applying autobiographical aspects in the novel. Back to Woolf's criticism of Sir Sidney Lee's biographies, one should notice that Woolf did not simply cramp her fiction with autobiographical details, but as she believed, she transformed them into an appealing and revealing form, radically different from the biographical conventions of her day.

One of the techniques Woolf employs in her fiction is the transformation or stylization of the self. In other words, she stylizes, modifies, and changes real life people in her fiction for technical purposes. For instance, Mrs. Ramsay, a typical Victorian woman in To the Lighthouse, represents patriarchal views of womanhood, but also resembles Woolf's mother, Julia Stephen, an intellectual whose educational impact on her children was great. So Mrs. Ramsay is modeled after Julia Stephen only when it is apt. Mr. Ramsay, furthermore, has been shown as a Sir Walter Scott fan, whereas it was Julia, rather than Leslie Stephen, that was an avid reader of Scott in the family. It is not clear why real life people are stylized into their fictional counterpart in such a distorted way, but the obvious thing is that Woolf did this to fit characters into the larger fictional gestalt that loomed out of the work, and in order to do that, she required to distort reality. That is why Leonard Woolf wrote: "there are traces of unfairness to Stephen in Ramsay" (Autobiography 116-17). Therefore, characters in Woolf's fiction transcend their autobiographical models, which is an affirmation of the fact that, in art, mixed feelings and multiple selves are resolved.

One of the influential devices to bring about this autobiographical semblance between Leslie and Mr. Ramsay was the alphabet image, which as Hussey suggests, might have sprung from Leslie Stephen's work as editor of the Dictionary of National Biography (1). Being an idealist, Mr. Ramsay has a linear perspective of man's intellectual progression directed towards truth as a fixed and ultimate goal, precisely like moving from ' $A$ ' to ' $Z$ ', ' $Z$ ' being the locale where truth could be discovered. Likewise, this teleological and idealistic view was a major feature of Leslie Stephen who considered himself less than a first rate intellectual: "He reached Q. Very few people in the whole of England ever reach Q. [...] But after Q? What comes next? After Q there are a number of letters the last of which is scarcely visible to mortal eyes, but glimmers red in the distance. $\mathrm{Z}$ is only reached once by one man in a generation" (To the Lighthouse 47-8). The foregrounding of certain images in Woolf's novels indicates her obsessions with images from her life memories that stuck in her mind and that she had to work out in fiction to release herself from and to reconcile with. Hence, the therapeutic effect Woolf sought in interpolating autobiographical issues into her fiction. Given that, the title of To the Lighthouse makes sense as an iconic locale that looms large in Woolf's childhood memories.

Di Laurea maintains that the modern art of biography in England looked up to Leslie Stephen for effecting changes in the genre and freeing it from its Victorian constrictions. Stephen had rendered true and "concise" accounts of the subject's life, nothing like lengthy and "embellished" Victorian biographies (46). Furthermore, Lytton Strachey, the "great master of biography" in 
Woolf's view (Letters 96), treated biography as an art form which focused on human nature and personality controlled by truthfulness, freedom of judgment, and avoidance of complacency (Skidelsky 6).

These innovations in the field of biography had a significant impact on Woolf's novels. The notion of truth and truthfulness in depicting the life of a person in a biography or a character in a novel wholly changed from the Victorian faithful journalistic reports on the appearance and superficial aspects to an in-depth understanding of what went on in the psyche of the individual. That is, there happened a shift from formal realism to psychological realism: "Look within and life, it seems, is very far from being 'like this.' Examine for a moment an ordinary mind on an ordinary day. The mind receives a myriad impressions - trivial, fantastic, evanescent, or engraved with the sharpness of steel. From all sides they come, an incessant shower of innumerable atoms; and as they fall, as they shape themselves into the life of Monday or Tuesday, the accent falls differently from of old" (Woolf, "Modern Fiction" 160).

Woolf's psychological realism and her disavowing of the formal and novelistic concerns of the Victorian era materialize in Mrs. Dalloway, a fragmentary account of characters and life situations in terms of sporadic and split beings and moments. This novel is famous for being (auto)biographically modeled after Woolf's own personality rather than those of her family members. The original title of the novel, The Hours was changed to the female protagonist's name, since Woolf preferred her novel of character to be epitomized by its new title, i.e. the name of Mrs. Dalloway as a character. This change in the title of the novel is significant regarding the reflection of Woolf's own hours and neurotic obsessions with the passage of time in her life. Here, Woolf's fears are narrated from diverse third person points of view. Since Woolf deploys the stream of consciousness as the major narrative technique in this novel, there are slippery shifts from one third person to another third person narrator, i.e. there are a number of narrators who push the story forward and backward, but there is no notice on the part of the writer about who narrates the story at a certain moment. Thus, the process of reading Mrs. Dalloway and recognizing and catching up with its numerous narrators challenge the readers and take a great deal of their energy.

Part of this energy is spent on the confusing and fragmentary selves within this novel, only for the readers to find out at the end that all these fragments belong to the life and character of Woolf herself, though each feature and fragment is contained by a different character in Mrs. Dalloway, now a woman, now a man, now young, now old. Examples abound: Woolf's own horror of the Great War and its aftermaths shows itself in Lucrezia, shell-shocked Septimus' Italian wife who echoes Conrad's famous "Horror! Horror! She wanted to cry" (Mrs. Dalloway 20). Likewise, the fear of death is embedded in the figure of Septimus, a war veteran who is diagnosed to be paranoiac, and commits suicide by falling out of a window in reaction to his doctor's decision to hospitalize him in a sanatorium. Woolf's suicide confirms her suicidal thoughts she shared with her male character Septimus, an alter ego for both Clarissa Dalloway and Virginia Woolf. Septimus and Woolf also share a hatred of authoritarian and inhumane doctors who do not understand their patients but in quantitative terms, as none of the psychiatrists Woolf referred to could help her out of her bedlam. Besides, Mrs. Dalloway's own fear of getting old and losing her beauty shows Woolf's own fear of the passage of time, where she quotes the famous statement from Shakespeare's Cymbeline: "Fear no more,' said Clarissa. Fear no more the heat o' the sun" (44).

All these characters put together with Clarissa Dalloway comprise Virginia Woolf, but one who is not a bit similar to real Woolf; that is, Woolf built upon characters in this novel is a fictional or stylized Woolf. The technique in this novel is the use of mirror fragments each of which reflects one particular feature of the whole, and this technique goes hand in hand with the stream of consciousness which facilitates the movement of the narrators from one moment to another in terms of free association of ideas. Woolf called the technique as "tunneling process" whereby she dug out beautiful caves behind her characters and these caves connected and came to daylight at the present moment (Woolf, The Diary 272).

So as one sees, Woolf produced several alter egos despite making Mrs. Dalloway the protagonist. She knew very well that this labyrinthine movement through the tunnels of a gigantic 
cave was the real way the mind moved around to produce a coherent perception of life. Therefore, she brought autobiographical associations into these caves to make her fictional characters lifelike on the page, and to distinguish herself from Victorian novelists, such as Dickens, Bennet, Wells, etc., whose sustenance depended on the creation of voluminous novels.

\section{CONCLUSIONS}

Both Colette and Woolf show autobiographical traces in their novels, so much so that one could call their fiction "autobiographical." Both admitted the inevitability of the influence of subjectivity as well as personal experience on their writings, and both not only welcomed this subgenre in novel but turned it into a very effective means to reach diverse objectives. One such objective was therapeutic effects for both novelists. In other words, reformulating their memories in their fiction, they reviewed or faced what weighed on their mind.

Colette took benefit of techniques such as mirroring, mask, makeup, and heredity to conjure up all the diverse dimensions of her "self" into a coherent being which no longer resembled the author. The shared point among these techniques is the blurring of the boundaries between self-revelation and self-concealment. It is by means of this duplicitous process that Colette introduces herself as an author whose chief concern is herself rather than anything else, and she is honest in this art. Woolf, too, does a similar job. Her techniques are: stylization, fragmentation, stream of consciousness, and tunneling process. Woolf sees the necessity of modifying real life personalities and events to make her fiction more effective. Like Colette, Woolf possesses numerous fictional selves which, combined together, build up her own character. Like Colette, Woolf is interested to bring to light the hidden persona of the figure behind fragments scattered in diverse caves. And precisely like Colette, she is criticized for distorting reality in her fiction.

Despite this, Woolf and Colette revived the subgenre of autobiographical fiction which had nearly died in the hands of their Victorian predecessors. Woolf and Colette did this in their own particular ways: Colette tried to produce a distinct feminine voice as the narrator of her autobiographical fiction, whereas Woolf adopted a more androgynous voice by bringing both genders together, and even by allotting her female characters with male alter egos. Colette defined all the criteria for her autobiographical fiction in her stories without being worried about producing theoretical commentaries on them, whereas Woolf rendered critical accounts of what she accepted as the codes of biographical writing in critical essays.

\section{References}

[1] Baladier L., “Autobiographie et fiction chez Colette.'” Cahiers Colette 15 (1993): 85-91.

[2] Baude M., "La distance dans La Vagabonde, techniques et thèmes romanesques." Nouvelles approches critiques. Paris: B. Bray, Nizet, 1986.

[3] Castillo M., Colette, une certaine France. Paris: Stock, 1999.

[4] Colette S.-G., La Naissance du jour. Paris: Garnier-Falmmarion, 1991.

[5] Colette S.-G., La Vagabonde. Paris: Albin Michel, 1992.

[6] Colette S.-G., Les Vrilles de la Vigne. Paris: Le Livre de Poche, 1995.

[7] Collado M. E., Colette, Lucie Delarue-Mardrus, Marcelle Tinayre. Émancipation et résignation. Paris: L'Harmattan, 2003.

[8] Di Laurea Tesi, “"Hanging Up Looking Glasses at Odd Corners': Virginia Woolf and Biography.” Diss. Universita Degli Studi di Padova, 2013/14.

[9] Ferrier-Caverivière N., Préface de La Maison de Claudine et Sido, Paris: Le Livre de Poche, 1990.

[10] Hériat Ph., “Colette, la femme cachée.” La Revue de Paris (1954): 9-15. 
[11] Hussey Mark, Virginia Woolf A to Z: A Comprehensive Reference for Students, Teachers and Common Readers to Her Life, Work and Critical Reception. New York: Oxford University, 1996.

[12] Itti E., La littérature du moi en 50 ouvrages. Autobiographie, mémoires, journaux intimes, récits autobiographiques. Paris: Ellipses, 1996.

[13] Laisné R., “Colette femme et écrivain.’” L’Express Magazine (1986): 24-6.

[14] Lejeune Ph., L’Autobiographie en France. Paris: A. Colin, Coll. «U2», 1971.

[15] Lejeune Ph., Le Pacte autobiographique. Paris: Seuil, 1975.

[16] Marks E., Colette. New Brunswick: Rutgers University, 1960.

[17] Skidelsky Robert, "Only Connect: Biography and Truth." The Troubled Face of Biography. Eds. Eric Homberger and John Charmley. Basingstoke: Macmillan, 1988. 1-16.

[18] Woolf Leonard, An Autobiography. Vol. 1. Oxford: Oxford University, 1980.

[19] Woolf Leonard, The Diary of Virginia Woolf (1915-1941). Vol. 2. Ed. Anne Olivier Bell and Andrew McNeillie. London: Hogarth, 1977-84.

[20] Woolf Virginia, Letters. Eds. Leonard Woolf and James Strachey. London: Hogarth, 1956.

[21] Woolf Virginia, "Modern Fiction." The Essays of Virginia Woolf. Vol. 4. Ed. Andrew McNeille (1925-1928). London: Hogarth, 1984. 157-66.

[22] Woolf Virginia, Mrs. Dalloway. Kent: Wordsworth Classics, 1996.

[23] Woolf Virginia, “The New Biography." Granite and Rainbow. London: Leonard Woolf, 1958. 149-155.

[24] Woolf Virginia, To the Lighthouse. Ed. Margaret Drabble. Oxford: Oxford University, 1992. 